\title{
Pseudomonas delhiensis sp. nov., from a fly ash dumping site of a thermal power plant
}

\author{
Om Prakash, Kirti Kumari and Rup Lal
}

Correspondence

Rup Lal

duzdel@vsnl.com

Molecular Biology Laboratory, Department of Zoology, University of Delhi, Delhi 110 007, India

\begin{abstract}
A phenanthrene- and citronellol-degrading bacterium, strain RLD-1 ${ }^{\top}$, was isolated from the fly ash dumping site of a thermal power plant in Delhi, India. The 16S rRNA gene sequence indicated that this strain belongs to the genus Pseudomonas; high levels of sequence similarity were found with respect to Pseudomonas citronellolis DSM $50332^{\top}$ (98.9\%), Pseudomonas jinjuensis DSM $16612^{\top}(97.6 \%)$ and Pseudomonas nitroreducens DSM $14399^{\top}(97.5 \%)$. Phylogenetic analysis based on 16S rRNA gene sequences placed the strain within the clade represented by these three strains. Strain RLD $-1^{\top}$ showed low levels of DNA-DNA hybridization with respect to $P$. citronellolis DSM $50332^{\top}$ (36\%), P. jinjuensis DSM $16612^{\top}(4 \%)$ and $P$. nitroreducens (13.7 \%). Strain RLD- $1^{\top}$ can also be distinguished from these three strains on the basis of several biochemical and physiological attributes. The novel strain contained high levels of cellular fatty acids $18: 1 \omega 7 c$, $16: 0$ and $16: 1 \omega 7 c$, along with $10: 03-\mathrm{OH}$ and $12: 03-\mathrm{OH}$. Thus, strain RLD-1 ${ }^{\top}$ represents a novel species of the genus Pseudomonas, for which the name Pseudomonas delhiensis sp. nov. is proposed. The type strain is RLD $-1^{\top}\left(=\right.$ MTCC $7601^{\top}=$ CCM $\left.7361^{\top}\right)$.
\end{abstract}

The genus Pseudomonas (Migula, 1894) represents a group of Gram-negative, non-spore-forming, motile, rod-shaped bacteria. It is an extremely heterogeneous group, and has been reclassified several times on the basis of phenotypic features (Sneath et al., 1981), rRNA-DNA hybridization (Palleroni, 1984), 16S rRNA gene sequence similarity (Anzai et al., 2000) and chemotaxonomic data (Oyaizu \& Komagata, 1983; Vancanneyt et al., 1996). Previously (Palleroni, 1984), members of the genus Pseudomonas were scattered throughout the classes Alphaproteobacteria, Betaproteobacteria and Gammaproteobacteria, but they are now restricted to the Gammaproteobacteria (with Pseudomonas aeruginosa as the type species); the members of the Alphaproteobacteria and Betaproteobacteria were transferred to other genera (Kersters et al., 1996; Anzai et al., 2000).

In the present study, a phenanthrene- and citronelloldegrading bacterial strain, RLD- $1^{\mathrm{T}}$, was isolated from the fly ash dumping site of a thermal power plant in Delhi, India, and found to use phenanthrene as the source of carbon and energy. Phylogenetic and taxonomic studies based on $16 \mathrm{~S}$ rRNA gene sequences, DNA-DNA hybridization data, fatty acid patterns and physiological and biochemical

The GenBank/EMBL/DDBJ accession number for the 16S rRNA gene sequence of strain RLD- $1^{\top}$ is DO339153.

DNA-DNA relatedness data are available in a supplementary table in IJSEM Online. characteristics showed that strain $\mathrm{RLD}-1^{\mathrm{T}}$ represents a novel species of the genus Pseudomonas.

Strain RLD- $1^{\mathrm{T}}$ was isolated by using an enrichment culture method (Samanta et al., 1999) with phenanthrene as the source of carbon and energy (Kiyohara et al., 1982). Colonies producing a clear zone due to phenanthrene degradation were isolated and purified on nutrient agar (NA) plates. Strain RLD-1 ${ }^{\mathrm{T}}$ showed luxuriant growth on citronellol, a natural acyclic monoterpenoid, which it degraded in liquid culture (data not shown). Interestingly, the phenanthrene-degrading ability was lost after two to three transfers on NA or Luria-Bertani (LB) agar, but the ability to degrade citronellol persisted.

Genomic DNA from strain RLD-1 ${ }^{\mathrm{T}}$ was extracted and purified as described by Pal et al. (2005). The 16S rRNA gene sequence was PCR-amplified (Robocycler 96; Stratagene) using a universal primer set corresponding to Escherichia coli positions 27F (16S forward primer: 5'-GAGTTTGATCCTGGCTCAG-3') and 1492R (16S reverse primer: $5^{\prime}$ TACGGTTACCTTGTTACGACTT-3'). The PCR product was run on a 3100 Avant Genetic Analyzer (Applied Biosystems) in the Department of Zoology, University of Delhi, India, using the MicroSeq Fullgene 16S rRNA gene sequencing kit. $16 \mathrm{~S}$ rRNA gene sequence similarity values were obtained using the SEQUENCE MATCH program of the Ribosomal Database Project (http://rdp.cme.msu.edu/html/) and BLAST (http://www.ncbi.nlm.nih.gov/blast/). 
To construct the phylogenetic tree, the 16S rRNA gene sequence of strain RLD $-1^{\mathrm{T}}$ was compared with $16 \mathrm{~S}$ rRNA gene sequences of 20 of the most closely related Pseudomonas species with validly published names. These 20 sequences were aligned using CLUSTALX (Thompson et al., 1997); common gaps from all of the selected sequences were removed and the alignment was checked manually for quality. Terminal nucleotides not common to all 20 sequences were removed. A phylogenetic analysis was carried out using the PHYLIP software package (version 3.5c; Felsenstein, 1993). An evolutionary distance matrix was calculated by using the distance model of Jukes \& Cantor (1969). An evolutionary tree (Fig. 1) was constructed using the neighbour-joining algorithm (Saitou \& Nei, 1987), and the resulting tree topology was evaluated by means of bootstrap analysis based on 1000 resamplings, using the SEQBOOT and CONSENSE programs in the PHYLIP package. A parsimony analysis (using DNAPARS) was also performed for the aligned sequence data, with bootstrapping based on 1000 resamplings.

A preliminary comparison of $1500 \mathrm{nt}$ of the $16 \mathrm{~S}$ rRNA gene sequence, conducted using the GenBank database, indicated that strain RLD $-1^{\mathrm{T}}$ has high levels of similarity with respect to P. citronellolis DSM $50332^{\mathrm{T}}$ (98.9\%), P. jinjuensis DSM $16612^{\mathrm{T}}(97.6 \%)$ and P. nitroreducens DSM $14399^{\mathrm{T}}(97.5 \%)$. Construction of a 16S rRNA gene sequence-based phylogenetic tree placed strain RLD- ${ }^{\mathrm{T}}$ in a monophyletic clade represented by $P$. citronellolis DSM $50332^{\mathrm{T}}$, P. jinjuensis DSM $16612^{\mathrm{T}}$ and P. nitroreducens DSM $14399^{\mathrm{T}}$. A similar phylogenetic relationship was also obtained by using a maximum-parsimony method (data not shown). The levels of 16S rRNA gene sequence similarity and the results of the phylogenetic analysis indicate that strain $R L D-1^{\mathrm{T}}$ is a member of the genus Pseudomonas and belongs to rDNA similarity group I (Palleroni, 1984) and the Pseudomonas aeruginosa group of Anzai et al. (2000).
$16 \mathrm{~S}$ rRNA gene sequences are not sufficient to allow discrimination between closely related species. The current gold-standard method for species delineation is DNA-DNA hybridization (Wayne et al., 1987; Stackebrandt \& Goebel, 1994). Thus, to clarify the taxonomic status of strain RLD- ${ }^{\mathrm{T}}$, DNA-DNA hybridization using the membrane filter method (Tourova \& Antonov, 1987) was performed with $P$. citronellolis DSM 50332 $2^{\mathrm{T}}, P$. jinjuensis DSM $16612^{\mathrm{T}}$ and $P$. nitroreducens DSM $14399^{\mathrm{T}}$ obtained from the Deutsche Sammlung von Mikroorganismen und Zellkulturen (Braunschweig, Germany). After extraction and purification, $10 \mu \mathrm{g}$ DNA from each strain was transferred onto a nylon membrane (Hybond-N; Amersham) in a dot-blot apparatus (Bio-Rad). The membrane was air-dried and UV cross-linked. DNA probes from each strain were labelled with $\left[\alpha_{-}^{32} \mathrm{P}\right] \mathrm{dATP}$ (Board of Radiation and Isotope Technology, Hyderabad, India), using a nick-translation kit (Bangalore Genei). Hybridization was performed overnight at $65^{\circ} \mathrm{C}$. After hybridization, the filters were washed twice, first with $0.5 \times$ SSC ( $3 \mathrm{M}$ sodium chloride, $0.3 \mathrm{M}$ sodium citrate; $\mathrm{pH} 7$ ) and $0.1 \%$ SDS for $10 \mathrm{~min}$ at room temperature and then with $0.1 \times$ SSC and $0.5 \%$ SDS for $20 \mathrm{~min}$ at $65^{\circ} \mathrm{C}$ to remove the unbound probe. The amount of bound probe DNA was estimated by using a scintillation counter (Beckman Instruments). DNA of strain RLD- $1^{\mathrm{T}}$ was bound to the filters and was hybridized with the DNA probe prepared from each of the reference strains. The DNA-DNA hybridization data showed that, at the genomic level, strain RLD- $1^{\mathrm{T}}$ has DNADNA relatedness values of 36,4 and $13.7 \%$, respectively, with P. citronellolis DSM $50332^{\mathrm{T}}, P$. jinjuensis DSM $16612^{\mathrm{T}}$ and $P$. nitroreducens DSM $14399^{\mathrm{T}}$. The percentage relatedness values, calculated on the basis of the data obtained (means of four replicates) from DNA-DNA hybridization are summarized in Supplementary Table S1 (available in IJSEM Online). These data both substantiated the results obtained from the $16 \mathrm{~S}$ rRNA gene sequence analysis and showed that strain RLD- $1^{\mathrm{T}}$ represents a novel species of the genus Pseudomonas.

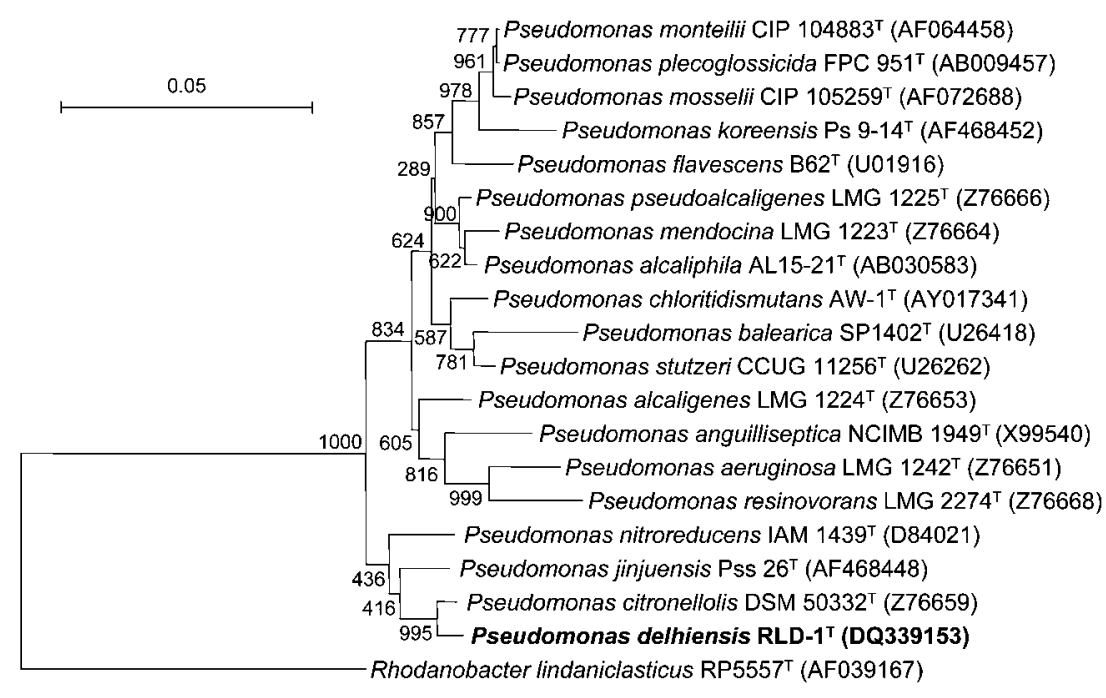

Fig. 1. Neighbour-joining phylogenetic tree, based on almost-complete 16S rRNA gene sequence, showing relationships of strain RLD $-1^{\top}$ with related members of the genus Pseudomonas. The tree was rooted by using Rhodanobacter lindanoclasticus RP5557 ${ }^{\top}$ as the outgroup. Numbers at nodes represent bootstrap values (based on 1000 resamplings). GenBank accession numbers are shown in parentheses. Bar, 0.05 nucleotide substitutions per nucleotide position. 
An analysis of the cellular fatty acids of strain RLD- ${ }^{\mathrm{T}}$ was carried out by Microbial ID (Newark, DE, USA) using the following procedure. Cultures of RLD-1 ${ }^{\mathrm{T}}$ were grown on TSBA (tryptic soya broth agar) and fatty acid methyl esters from $40 \mathrm{mg}$ cells scraped from Petri dishes were analysed by saponification, methylation and extraction using the method of Sasser (1990). The fatty acid methyl esters were separated using the Sherlock Microbial Identification System (Microbial ID), consisting of an Agilent model 5980 gas chromatograph fitted with a phenyl methyl silicon column $(25 \mathrm{~m} \times 0.2 \mathrm{~mm})$ and a flame ionization detector. Identification and comparison were carried out using the Aerobe (TSBA 50, version 5) databases of the Sherlock Microbial Identification system. Strain RLD- ${ }^{\mathrm{T}}$ contained $10: 03-\mathrm{OH}(3.62 \%), 12: 0$ (4.61\%), $12: 02-\mathrm{OH}(4.83 \%)$, $12: 03-\mathrm{OH}(4.67 \%), 14: 0(1.10 \%), 15: 0$ (trace amount), $16: 0(23.81 \%), 17: 0$ cyclo $(3.70 \%), 18: 1 \omega 7 c(32.56 \%)$, 19: 0 cyclo $\omega 8 c(2.07 \%)$ and summed feature $3(16: 1 \omega 7 c$ and/or iso-15:0 2-OH; $19.03 \%)$. A comparative analysis of the fatty acid profile of strain RLD- $1^{\mathrm{T}}$ with those in the TSBA 505 library of MIDI produced the closest match with $P$. aeruginosa (similarity index value, 0.469 ). The presence of high levels of $18: 1 \omega 7 c, 16: 0$ and $16: 1 \omega 7 c$, along with $10: 0$ 3-OH and 12:0 3-OH, also showed good agreement with the fatty acid patterns of members of the genus Pseudomonas, indicating that strain RLD $-1^{\mathrm{T}}$ is a member of the genus Pseudomonas.

The morphological features of colonies of strain RLD- $1^{\mathrm{T}}$ (i.e. shape, size, colour, contours and pigment production) were studied on NA and on LB agar plates after $72 \mathrm{~h}$ incubation at $37^{\circ} \mathrm{C}$. Colonies were muddy white, each having a greyish spot in the centre. Gram staining and spore staining were done using Himedia kits. The size of the organism (obtained using micrometry) was approximately $0.5 \times 1.5 \mu \mathrm{m}$. The motility of the micro-organism was studied by using the hanging drop method and by using motility agar (Farmer, 1999). For observation of the cell morphology by transmission electron microscopy, cells were grown on LB media and suspended in physiological saline solution. A small drop of suspension was placed on a carbon-coated copper grid and cells were negatively stained with $0.5 \%$ uranyl acetate for observation under a transmission electron microscope (model 269D; Morgagni). Strain RLD- $1^{\mathrm{T}}$ was found to be a Gram-negative, non-sporeforming, rod-shaped bacterium, each cell bearing a single polar flagellum (Fig. 2). Antibiotic-sensitivity tests were performed on Mueller-Hinton II medium using readymade Sensi-discs (Himedia) containing various amounts of antibiotic. Strain RLD- ${ }^{\mathrm{T}}$ was found to be sensitive to oxytetracycline $(30 \mu \mathrm{g})$, tetracycline $(30 \mu \mathrm{g})$, chlortetracycline $(30 \mu \mathrm{g})$, kanamycin $(30 \mu \mathrm{g})$, streptomycin $(10 \mu \mathrm{g})$, gentamicin $(10 \mu \mathrm{g})$ and neomycin $(30 \mu \mathrm{g})$, but was found to be resistant to nalidixic acid $(30 \mu \mathrm{g})$, rifamycin $(5 \mu \mathrm{g})$, novobiocin $(30 \mu \mathrm{g})$, vancomycin $(30 \mu \mathrm{g})$, penicillin $\mathrm{G}$ $(10 \mu \mathrm{g})$, ampicillin $(10 \mu \mathrm{g})$, amoxicillin $(10 \mu \mathrm{g})$, erythromycin $(15 \mu \mathrm{g})$ and chloramphenicol $(30 \mu \mathrm{g})$. A catalase test and tests of growth at different temperatures were carried

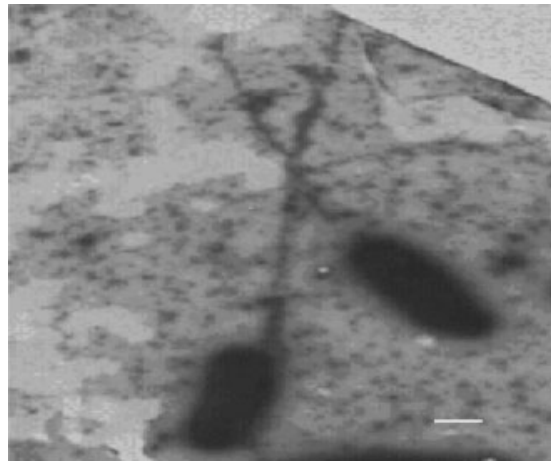

Fig. 2. Transmission electron micrograph of negatively stained cells of strain $\mathrm{RLD}-1^{\top}$, showing the single polar flagellum. Bar, $0.5 \mu \mathrm{m}$.

out as described by McCarthy \& Cross (1984). To study growth at different temperatures, a $1.0 \%(\mathrm{v} / \mathrm{v})$ inoculum of strain RLD- $1^{\mathrm{T}}\left(\mathrm{OD}_{600}=0.5\right)$ was added to nutrient broth incubated at different temperatures on a Lab-Line Orbit Environ shaker at 200 r.p.m. Growth was monitored by measuring the $\mathrm{OD}_{600}$. Optimum growth was observed at $37^{\circ} \mathrm{C}$. Hydrolysis of aesculin and Tween 80 by RLD $-1^{\mathrm{T}}$ and the ability of the strain to grow in the presence of $\mathrm{NaCl}$ were tested as described by Arden Jones et al. (1979). In contrast to P. citronellolis DSM $50332^{\mathrm{T}}$ and P. jinjuensis DSM $16612^{\mathrm{T}}$, strain RLD- ${ }^{\mathrm{T}}$ did not degrade aesculin but did hydrolyse Tween 80 and hypoxanthine (Table 1). Urease activity was detected as described by Christensen (1946). Acid production from carbohydrates and the degradation of xanthine and hypoxanthine were tested as described by Gordon et al. (1974). Other physiological tests and methods were as described by Collins et al. (1989). In contrast to $P$. citronellolis DSM 50332 ${ }^{\mathrm{T}}$, P. jinjuensis DSM $16612^{\mathrm{T}}$ and $P$. nitroreducens DSM $14399^{\mathrm{T}}$, strain RLD- $1^{\mathrm{T}}$ was able to utilize ribose and galactose (Table 1). The differences between the chemical and physiological data for strain RLD- $1^{\mathrm{T}}$ and those for the related strains $P$. citronellolis DSM $50332^{\mathrm{T}}, P$. jinjuensis DSM $16612^{\mathrm{T}}$ and $P$. nitroreducens DSM $14399^{\mathrm{T}}$ support the results of $16 \mathrm{~S}$ rRNA gene sequence analysis, DNA-DNA hybridizations and fatty acid analysis and indicate that strain $\mathrm{RLD}-1^{\mathrm{T}}$ is distinct from these strains. The tree topology also strongly suggested that strain RLD $-1^{\mathrm{T}}$ is a member of the genus Pseudomonas. Thus, strain RLD- ${ }^{\mathrm{T}}$ represents a novel species of Pseudomonas, for which the name Pseudomonas delhiensis sp. nov. is proposed.

\section{Description of Pseudomonas delhiensis sp. nov.}

Pseudomonas delhiensis (del.hi.en'sis. N.L. fem. adj. delhiensis pertaining to Delhi, the place of isolation of the type strain).

Cells are Gram-negative, aerobic, non-spore-forming, motile rods $(0.5 \times 1.5 \mu \mathrm{m})$ bearing a single polar flagellum. Colonies are smooth and circular, muddy white with a greyish central spot $(1.5 \mathrm{~mm}$ in diameter on NA and 
Table 1. Differential phenotypic characteristics of strain $R L D-1^{\top}$ with respect to related members of the genus Pseudomonas

Strains: 1, strain RLD-1 ${ }^{\mathrm{T}}$; 2, P. citronellolis DSM 50332 $2^{\mathrm{T}}$;, P. jinjuensis DSM $16612^{\mathrm{T}} ; 4$, P. nitroreducens DSM $14399^{\mathrm{T}}$. + , Positive; ++ , strongly positive; - , negative. Data are from this study unless indicated.

\begin{tabular}{|c|c|c|c|c|}
\hline Characteristic & 1 & 2 & 3 & 4 \\
\hline Cell size $(\mu \mathrm{m})$ & $0.5 \times 1.5$ & $1.1 \times 3.1$ & $0.4 \times 2.1$ & $1.0 \times 3.0$ \\
\hline Fluorescence on King's B medium & - & $t^{*}$ & $-{ }^{*}$ & - \\
\hline \multicolumn{5}{|l|}{ Growth at/with: } \\
\hline $4{ }^{\circ} \mathrm{C}$ & + & $+^{*}$ & $-{ }^{\star}$ & + \\
\hline $41^{\circ} \mathrm{C}$ & + & $+^{*}$ & $-{ }^{*}$ & - \\
\hline $5 \% \mathrm{NaCl}$ & ++ & $+^{*}$ & $-^{*}$ & + \\
\hline Degradation of citronellol & + & $+^{*}$ & $-{ }^{*}$ & - \\
\hline \multicolumn{5}{|l|}{ Hydrolysis of: } \\
\hline Aesculin & - & + & + & - \\
\hline Tween 80 & + & - & - & + \\
\hline Hypoxanthine & ++ & + & ++ & + \\
\hline \multicolumn{5}{|l|}{ Production of: } \\
\hline Urease & + & ++ & - & + \\
\hline Gelatinase & - & - & + & - \\
\hline \multicolumn{5}{|l|}{ Acid production from: } \\
\hline Adonitol & + & - & + & - \\
\hline Dulcitol & - & - & + & - \\
\hline Glucose & + & - & + & - \\
\hline Mannitol & - & - & + & - \\
\hline Ribose & + & - & - & - \\
\hline Xylose & + & - & + & - \\
\hline Fructose & ++ & + & ++ & ++ \\
\hline Galactose & + & - & - & - \\
\hline Arabinose & + & - & + & - \\
\hline Glycerol & + & + & ++ & + \\
\hline
\end{tabular}

${ }^{\star}$ Data from Kwon et al. (2003).

$2.0 \mathrm{~mm}$ on $\mathrm{LB}$ agar after $72 \mathrm{~h}$ incubation at $37^{\circ} \mathrm{C}$ ). Positive for oxidase, catalase, nitrate reductase and urease and negative for gelatinase and amylase. Acid is produced from glycerol, lactose, mannitol, glucose, dextrin, sucrose, Larabinose, D-fructose, D-galactose, xylose, D-trehalose, cellobiose and sorbitol. Sensitive to the following antibiotics $(\mu \mathrm{g})$ : oxytetracycline (30), tetracycline (30), chlortetracycline (30), kanamycin (30), streptomycin (10), gentamicin (10), neomycin (30). Resistant to the following antibiotics $(\mu \mathrm{g})$ : nalidixic acid (30), rifamycin (5), novobiocin (30), vancomycin (30), penicillin G (10), ampicillin (10), amoxicillin (10), erythromycin (15) and chloramphenicol (30). The fatty acid profile contains $10: 03-\mathrm{OH}(3.62 \%)$, $12: 0$ (4.61\%), $12: 02-\mathrm{OH}(4.83 \%), 12: 03-\mathrm{OH}(4.67 \%)$, $16: 0(23.81 \%), 17: 0$ cyclo $(3.70 \%), 18: 1 \omega 7 c(32.56 \%)$, $19: 0$ cyclo $\omega 8 c(2.07 \%)$ and summed feature $3(16: 1 \omega 7 c$ l iso-15:0 2-OH; $19.03 \%)$. The optimum temperature for growth is $37^{\circ} \mathrm{C}$.

The type strain, RLD- $1^{\mathrm{T}}\left(=\operatorname{MTCC} 7601^{\mathrm{T}}=\operatorname{CCM} 7361^{\mathrm{T}}\right)$, was isolated from the fly ash dumping site of a thermal power plant in Delhi, India, and has the capacity to degrade phenanthrene and citronellol.

\section{Acknowledgements}

Part of this work was supported by grants from the Department of Biotechnology (DBT), Government of India. We gratefully acknowledge SAIF-DST (Sophisticated Analytical Instrumentation FacilityDepartment of Science and Technology, Department of Anatomy - AIIMS) for providing the transmission electron microscopy facility. O.P. and K. K. acknowledge CSIR-UGC (Government of India) for research fellowships. We would like to thank J. P. Euzéby for etymological advice and J. S. Bhatti for critical reading of the manuscript.

\section{References}

Anzai, Y., Kim, H., Park, J.-Y., Wakabayashi, H. \& Oyaizu, H. (2000). Phylogenetic affiliation of pseudomonads based on 16S rRNA sequence. Int J Syst Evol Microbiol 50, 1563-1589.

Arden Jones, M. P., McCarthy, A. J. \& Cross, T. (1979). Taxonomic and serological studies on Micropolyspora faeni and Micropolyspora 
strains from soil bearing the specific epithet rectivirgula. J Gen Microbiol 115, 343-354.

Christensen, W. B. (1946). Urea decomposition as a means of differentiating Proteus and Paracolon cultures from each other and from Salmonella and Shigella types. J Bacteriol 52, 461-466.

Collins, C. H., Lyne, P. M. \& Grange, J. M. (1989). Collins and Lyne's Microbiological Methods, 6th edn. Oxford: Butterworth.

Farmer, J. J., III (1999). Enterobacteriaceae: introduction and identification. In Manual of Clinical Microbiology, 7th edn, pp. 442-458. Edited by P. R. Murray, E. J. Baron, M. A. Pfaller, F. C. Tenover \& R. H. Yolken. Washington, DC: American Society for Microbiology.

Felsenstein, J. (1993). PHYLIP (phylogeny inference package), version 3.5c. Department of Genome Sciences, University of Washington, Seattle, USA.

Gordon, R. E., Barnett, D. A., Handerhan, J. E. \& Pang, C. H.-N. (1974). Nocardia coeliaca, Nocardia autotrophica, and the nocardin strain. Int J Syst Bacteriol 24, 54-63.

Jukes, T. \& Cantor, C. R. (1969). Evolution of protein molecules. In Mammalian Protein Metabolism, pp. 21-132. Edited by H. N. Munro. New York: Academic Press.

Kersters, K., Ludwig, W., Vancanneyt, M., De Vos, P., Gillis, M. \& Schleifer, K. H. (1996). Recent changes in the classification of the pseudomonads: an overview. Syst Appl Microbiol 19, 465-477.

Kiyohara, H., Nagao, K., Kouno, K. \& Yano, K. (1982). Phenanthrenedegrading phenotype of Alcaligenes faecalis AFK2. Appl Environ Microbiol 43, 458-461.

Kwon, S. W., Kim, J. S., Park, I. C., Yoon, S. H., Park, D. H., Lim, C. K. \& Go, S. J. (2003). Pseudomonas koreensis sp. nov., Pseudomonas umsongensis sp. nov. and Pseudomonas jinjuensis sp. nov., novel species from farm soils in Korea. Int J Syst Evol Microbiol 53, 21-27.

McCarthy, A. J. \& Cross, T. (1984). A taxonomic study of Thermomonospora and other monosporic actinomycetes. J Gen Microbiol 130, 5-25.

Migula, W. (1894). Über ein neues System der Bakterien. Arb Bakteriol Inst Karlsruhe 1, 235-238 (in German).

Oyaizu, H. \& Komagata, K. (1983). Grouping of Pseudomonas species on the basis of cellular fatty acid composition and the quinone system with special reference to the existence of 3-hydroxy fatty acids. J Gen Appl Microbiol 29, 17-40.

Pal, R., Bala, S., Dadhwal, M., Kumar, M., Dhingra, G., Prakash, O., Prabagaran, S. R., Shivaji, S., Cullum, J. \& other authors (2005).
Hexachlorocyclohexane-degrading bacterial strains Sphingomonas paucimobilis B90A, UT26 and Sp+, having similar lin genes, represent three distinct species, Sphingobium indicum sp. nov., Sphingobium japonicum sp. nov. and Sphingobium francense sp. nov., and reclassification of [Sphingomonas] chungbukensis as Sphingobium chungbukense comb. nov. Int J Syst Evol Microbiol 55, 1965-1972.

Palleroni, N. J. (1984). Genus I. Pseudomonas Migula 1894, $237^{\mathrm{AL}}$. In Bergey's Manual of Systematic Bacteriology, vol. 1, pp. 141-199. Edited by N. R. Krieg \& J. G. Holt. Baltimore: Williams \& Wilkins.

Saitou, N. \& Nei, M. (1987). The neighbor-joining method: a new method for reconstructing phylogenetic trees. Mol Biol Evol 4, 406-425.

Samanta, S. K., Chakraborti, A. K. \& Jain, R. K. (1999). Degradation of phenanthrene by different bacteria: evidence for novel transformation sequences involving the formation of 1-naphthol. Appl Microbiol Biotechnol 53, 98-107.

Sasser, M. (1990). Identification of bacteria by gas chromatography of cellular fatty acids. Technical Note 101. Newark, DE: MIDI Inc.

Sneath, P. H. A., Stevens, M. \& Sackin, M. J. (1981). Numerical taxonomy of Pseudomonas based on published record of substrate utilization. Antonie van Leeuwenhoek 47, 423-448.

Stackebrandt, E. \& Goebel, B. M. (1994). Taxonomic note: a place for DNA-DNA reassociation and 16S rRNA sequence analysis in the present species definition in bacteriology. Int J Syst Bacteriol 44, 846-849.

Thompson, J. D., Gibson, T. J., Plewniak, F., Jeanmougin, F. \& Higgins, D. G. (1997). The CLUSTAL_X windows interface: flexible strategies for multiple sequence alignment aided by quality analysis tools. Nucleic Acids Res 25, 4876-4882.

Tourova, T. P. \& Antonov, A. S. (1987). Identification of microorganisms by rapid DNA-DNA hybridization. Methods Microbiol 19, 333-355.

Vancanneyt, M., Witt, S., Abraham, W.-R., Kersters, K. \& Fredrickson, H. L. (1996). Fatty acid content in whole-cell hydrolysates and phospholipid fractions of pseudomonads: a taxonomic evaluation. Syst Appl Microbiol 19, 528-540.

Wayne, L. G., Brenner, D. J., Colwell, R. R., Grimont, P. A. D., Kandler, O., Krichevsky, M. I., Moore, L. H., Moore, W. E. C., Murray, R. G. E. \& other authors (1987). International Committee on Systematic Bacteriology. Report of the ad hoc committee on reconciliation of approaches to bacterial systematics. Int $J$ Syst Evol Microbiol 37, 463-464. 